control of these weed species.

Pyrithiobac sodium is an ALS inhibitor so nightshade growth is quickly arrested and ultimate plant death is slow, occurring over a period of 3 to 4 weeks. Cultivation enhances control by throwing dirt to the base of the cotton plant, covering the affected nightshade plants.

Future research will be conducted to address timing and rates for effective use in Pima (Gossypium barbadense) cotton and to determine the extent of antagonism when Staple is tank mixed with the selective postemergence grass herbicides fluazifop-P (Fusilade), sethoxydim (Poast) and clethodim (Prism).

R. Vargas is Farm Advisor and T.M. Martin-Duvall is Staff Research Associate, UC Cooperative Extension, Madera County; S. Wright is Farm Advisor and M. Jimenez Jr. is Staff Research Associate, UCCE, Tulare County.

\section{References}

Jachetta J. 1996. Amino acid inhibition herbicides. California Weed Science Society Proc 48:135-41. Jan 21-23, 1996. Sacramento, CA.

Keeley PE, Thullen RJ. 1988. Growth and early production of black nightshade in cotton. California Weed Science Society Proc 40:220-1. Jan 18-21, 1988. Sacramento, CA.

Keeley PE, Thullen RJ. 1991. Biology and control of black nightshade (Solanum nigrum) in cotton (Gossypium hirsutum). Weed Technology 5:713-22

Kempen HM. 1986. Nightshade, cotton's no. 1 enemy. California Weed Science Society Proc 38:136-44. Jan 27-30, 1986. Fresno, CA.

Martin-Duvall TM. 1996. Effects of adjuvants and Fusilade on the efficacy of Staple on nightshade in cotton. Fresno, CA: California State University Fresno.

Vargas RN, Fischer WB, Kempen HM, Wright SD. 1996. Cotton weed management. Cotton Production Manual. University of California, DANR, Publication \#3352. p. 187.

Vargas RN, Wright SD. 1994. Nightshade control with pyrithiobac sodium (Staple) in California cotton. Challenging the Future. World Cotton Conference Proc 1:191-3. Feb. 14-17, 1994. Brisbane, Australia

Vargas RN, Wright SD, Martin-Duvall TM, Jimenez Jr. M. 1996a. Control of nightshade in cotton with Staple (pyrithiobac sodium) and its effect on rotational crops in California. Western Society of Weed Science Proc 49:90. Mar 11-14, 1996 Albuquerque, NM.

Vargas RN, Martin-Duvall TM, Wright SD, Jimenez Jr. M. 1996b. Staple: Is it the silver bullet for cotton. California Weed Science Society Proc 48:100-6. Jan 22-24, 1996. Sacramento, CA.

\title{
Curly top virus found in perennial shrubs in foothills
}

\author{
R. Michael Davis $\square$ Heping Wang $\square$ Bryce W. Falk \\ Joe J. Nunez
}

Beet curly top geminivirus damages numerous crops, including beans, beets, spinach, peppers, melons and tomatoes. Both the virus and its vector, the beet leafhopper, overwinter in the foothills surrounding the Central Valley. The known host range of the virus is now recognized to include many native and introduced perennial shrubs in the foothills. This is the first reported detection of the virus in plants in the families Ephedraceae, Rhamnaceae and Salicaceae.

In North America, the beet curly top geminivirus is transmitted only by the beet leafhopper. Both the disease and the leafhopper have extensive host ranges and are widespread throughout the western United States. If susceptible crops are visited by large numbers of viruliferous leafhoppers, the disease can cause crop losses near $100 \%$ in individual fields. The epidemiology of curly top disease - so named because of the bunchy, twisted foliage characteristic of many infected crop plants - is complex and disease control is difficult.

The native vegetation of California does not allow the buildup of large populations of the beet leafhopper, Circulifer tenellus, but several generations are produced on introduced mustards, Russian thistle, and other annual weeds over the summer. During this time the beet leafhopper may visit crop plants and transmit beet curly top geminivirus (BCTV) while feeding, even though the crop may not be a preferred host (e.g., tomato). As crops and annual weeds dry in the autumn, the beet leafhopper moves back to breeding areas in the foothills and overwinters on perennials. When spring rains germinate various annuals including mustards, peppergrass and filaree, leafhoppers congregate and lay eggs on these plants on warm, sunny slopes. As these hosts mature and dry, the next generation of beet leafhoppers migrates to agricultural lands to feed on crops and nearby weeds such as Russian thistle (Bennett 1971). At some point in its life, the insect may feed on BCTV-infected plants and acquire the virus, which it can then transmit for the remainder of its life.

The purpose of this study was to determine if native and introduced

\section{Editor's note}

\begin{abstract}
"New pests and plant diseases," survey articles describes new pests and diseases of statewide significance. We are publishing this new research section as an experiment. In the last 3 years, California Agriculture has not printed articles of this nature because they do not meet the test of containing 2 years of experimental data. However, we feel that these articles may provide important information to our readers. Please let us know what you think about this, and whether articles of this nature present information important to you.
\end{abstract}


perennial shrubs in the coastal hills west of the Central Valley serve as reservoirs of BCTV. The virus is not transmitted through seed, so plants that harbor BCTV year after year could be an important component in the epidemiology of the disease.

We collected leaves from shrubs in the Coastal Range foothills of Merced, Stanislaus, Kern and Santa Barbara counties during spring and summer 1997. Plants were collected at random, since no symptoms were observed on any perennial in this survey (unlike crop plants, which readily exhibit typical curly top symptoms). We determined BCTV infection in each sample by the presence or absence of BCTV DNA in plant sap. To extract the DNA, 200 milligrams of leaf tissue from each sample was ground into a fine powder in liquid nitrogen and suspended in buffer. Crude DNA in each sample was extracted in phenol and chloroform, precipitated in ethanol, and applied to nylon membranes as duplicated dots. The membranes were then subjected to hybridization analysis with an antibody-linked, BCTV DNA probe and exposed to X-ray film. A sample that contained BCTV DNA showed dark spots with an intensity visibly greater than extracts from noninfected controls.

We detected BCTV in 11 different perennial shrubs from nine different plant families (table 1). This is the first report of the occurrence of BCTV in all of these host plants and the first report of the virus in plants in the families Ephedraceae,

Rhamnaceae and

Salicaceae. The incidence of BCTV in Ceanothus cuneatus (buck brush), a common member of the California chaparral community, was particularly high. We collected samples of buck brush on three occasions, since the incidence of infection was notable. Two isolates of BCTV from buck brush and one isolate from a willow were transferred by leafhoppers to herbaceous plants in the greenhouse. These isolates are currently maintained at UC Davis.

BCTV apparently occurs in a wide variety of native and introduced perennial shrubs; the small collection of samples in this survey of 36 plant species precludes limiting the host range to those species that were found to be infected. There was no bias toward symptomatic plants (because no obvious viral symptoms were found in BCTV-infected shrubs); considering this, the frequency of BCTV infection in these
TABLE 1. Beet curly top geminivirus-infected perennial shrubs sampled in hills west of the San Joaquin Valley

\begin{tabular}{llrr}
\hline Family & \multicolumn{1}{c}{ Species } & No. infected & No. tested \\
\hline \hline Asteraceae & Chrysothamnus sp. (rabbitbrush) & 3 & 22 \\
& unidentified composite & 1 & 2 \\
Ephedraceae & Ephedra viridis (green ephedra) & 1 & 9 \\
Fabaceae & Astragalus sp. (milkvetch) & 1 & 4 \\
& Lotus sp. & 1 & 5 \\
Hydrophyllaceae & Eriodictyon californicum (yerba santa) & 3 & 12 \\
Lamiaceae & Mentha pulegium (pennyroyal) & 1 & 4 \\
Polygonaceae & Eriogonum fasciculatum (California buckwheat) & 1 & 10 \\
Rhamnaceae & Ceanothus cuneatus (buck brush) & 20 & 25 \\
Salicaceae & Salix sp. (willow) & 5 & 20 \\
Solanaceae & Nicotiana glauca (tree tobacco) & 1 & 16 \\
\hline
\end{tabular}

Note: Beet curly top geminivirus was not detected in samples of Adenostoma fasciculatum (chamise), Aesculus californica (California buckeye), Arctostaphylos sp. (manzanita), Artemesia tridentata (sagebrush), Atriplex polycarpa (saltbush), Baccharis pilularis (coyote brush), Baccharis salicifolia (mule fat), Croton californicus, Encelia actoni, Epilobium canum (California fuchsia), Eriophyllum confertiflorum (golden yarrow), Garrya flavescens (silk tassel), Heteromeles arbutifolia (toyon), Isomeris arborea (bladderpod), Juniperus occidentalis (juniper), Marrubium vulgare (horehound), Mimulus sp. (monkeyflower), Penstemon centranthifolius (scarlet bugler), Penstemon heterophyllus (beardtongue), Phacelia sp., Quercus berberidifolia (scrub oak), Ribes sp. (currant), Salvia mellifera (black sage), Solanum sp. (nightshade), and Toxicodendron diversilobum (poison oak). An average of seven plants of each species was evaluated.

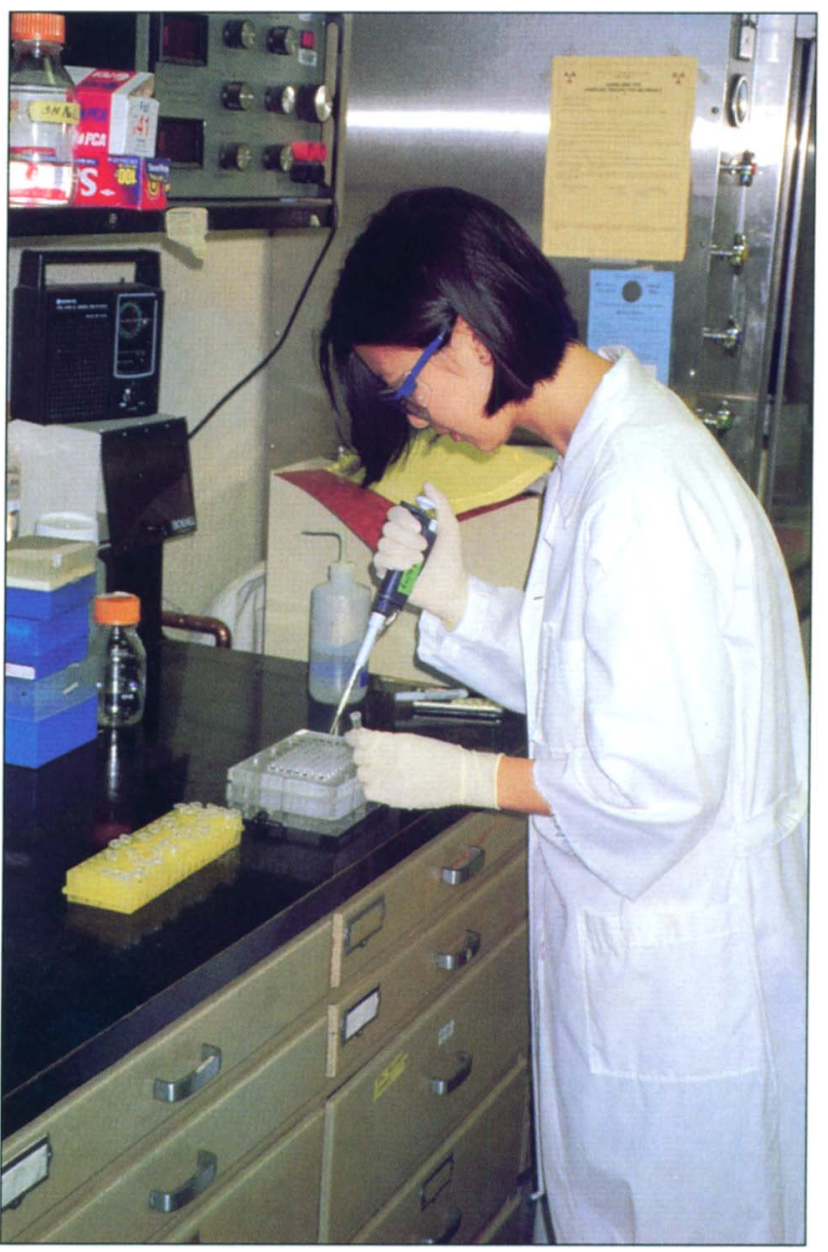

Lab technician Grace Kao prepares plant DNA samples for beet curly top virus dot blot analysis.

perennial shrubs was surprisingly high. While it has long been suspected that perennial plants in the foothills harbored the virus, in fact, the virus appears to be commonplace among them.

Present management strategies for reducing curly top disease include spraying insecticides on leafhopper breeding grounds to reduce populations of the insects before they migrate to crops in the Central Valley, eliminating weed reservoirs, and planting BCTV-resistant varieties, when available. In an effort to control BCTV and the beet leafhopper in California, growers pay over $\$ 1$ million annually to spray up to 100,000 foothill acres with insecticides. This program may prevent catastrophic losses to curly top, but doesn't account for long distance movement of the beet leafhopper, which is a strong flier and may migrate hundreds of miles to cultivated areas (Bennett 1971). 
Heretofore, studies on the natural incidence of BCTV in California concentrated on annual weeds and crop plants (Creamer et al. 1996). This study increases the known host range of the virus to include many perennial shrubs. The importance of this large reservoir of the virus is yet unknown, but these perennial shrubs may prove to be an important component in the epidemiology of curly top disease.

R.M. Davis is Cooperative Extension Specialist, $H$. Wang was Postgraduate Researcher and B.W. Falk is Professor, Department of Plant Pathology, UC Davis; and J.J. Nunez is Farm Advisor, UC Cooperative Extension, Kern County.

\section{References}

Bennett CW. 1971. The curly top disease of sugarbeet and other plants. Amer Phytopathological Society Monograph No. 7.

Creamer R, Luque-Williams M, Howo M. 1996. Epidemiology and incidence of beet curly top geminivirus in naturally infected weed hosts. Plant Disease 80:533-5.

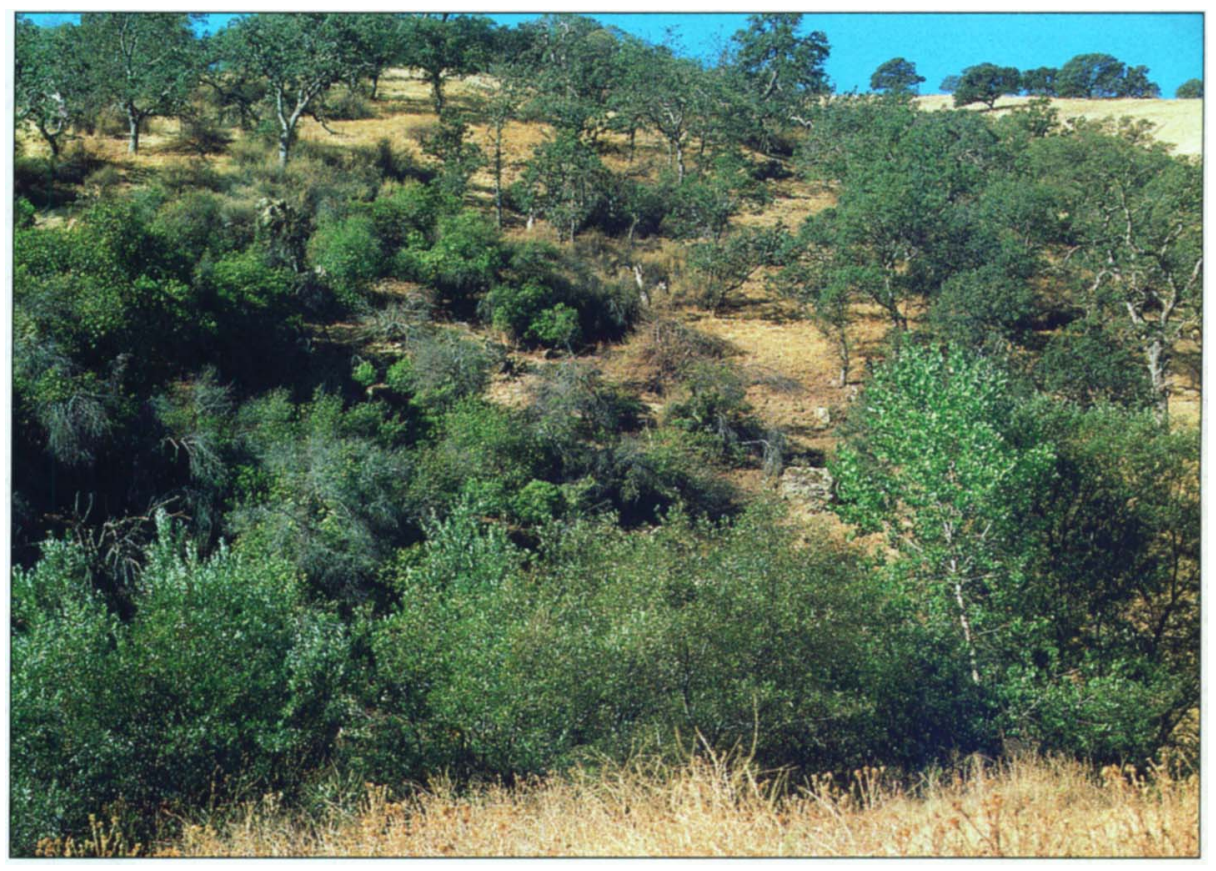

$\Delta$ The known host range of the beet curly top geminivirus is recognized to include many perennial shrubs in the foothills. Incidence of the virus in buck brush, a common member of the California chaparral community, was particularly high.

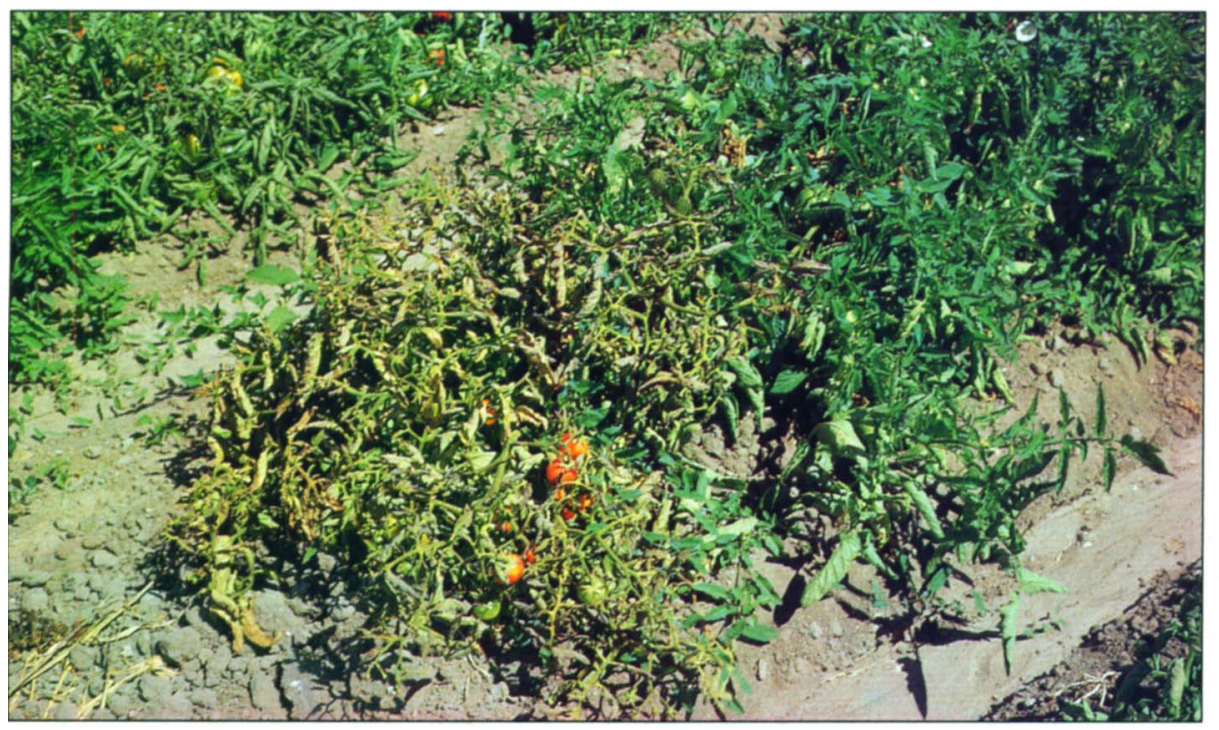

4 Tomatoes have no genetic resistance to curly top - so named because of the bunchy, twisted foliage characteristic of infected plants.

$\nabla$ In North America, the beet curly top geminivirus is transmitted only by the beet leafhopper.

\section{CALIFORNIA AGRICULTURE ASSOCIATE EDITORS}

Animal, Avian, Aquaculture \& Veterinary Sciences Christopher M. Dewees Kathryn Radke Bennie I. Osburn Barbara A. Reed

Economics \& Public Policy Richard A. Howitt Alvin Sokolow

\section{Food \& Nutrition}

Barbara Schneeman

Eunice Williamson

\author{
Human \& Community \\ Development \\ Linda M. Manton \\ Karen P. Varcoe \\ Land, Air \& Water Sciences \\ Garrison Sposito \\ Henry J. Vaux, Jr. \\ Natural Resources \\ Barbara H. Allen-Diaz \\ Daniel W. Anderson \\ Richard B. Standiford
}

http://danr.ucop.edu/calag/

CALAG@ucop.edu

$\mathrm{PH}: 510$ 987-0044

FAX: $510465-2659$

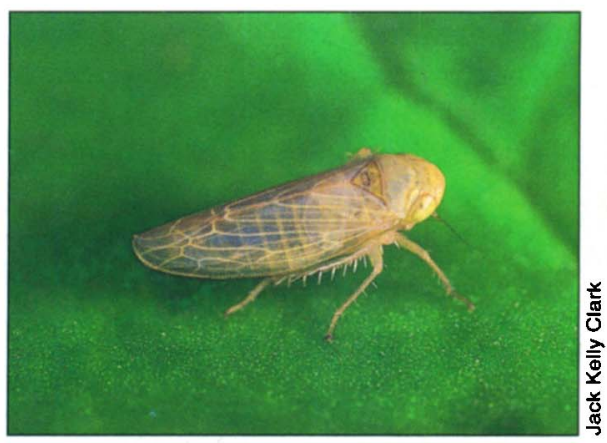

